УДК 33.332 .1

JEL Classification: R11; R58; O18

ВАСИЛЬЧЕНКО А. О. ${ }^{1}$, ДЕМ'ЯНОВ С. О. ${ }^{2}$

\title{
АНАЛІЗ ЕКОНОМІКО-ГЕОГРАФІЧНИХ ПІДХОДІВ ДО ІДЕНТИФІКАЦЇ̈ РЕГІОНАЛЬНИХ КЛАСТЕРІВ
}

DOI: $10.32620 /$ cher.2021.3.02

Постановка проблеми. Ця стаття присвячена дослідженню проблематики економікогеографічних підходів до ідентифікації кластерів на регіональному рівні. Більшість сучасних наукових досліджень ідентифікації регіональних кластерів направлено на вивчення економічних аспектів, практично повністю ігноруючи геопросторові чинники. Метою даного дослідження є аналіз економіко-географічних підходів до ідентифікації кластерів на регіональному рівні з урахуванням проблеми змінності одиниць площі. Предметом дослідження виступає дослідження підходів щодо ідентифікації кластерів на регіональному рівні. В ході дослідження застосовано такі методи як: порівняльний, статистичний, описовий, системний, аналіз і синтез. Гіпотеза дослідження. Виявлення методичних обмежень методів ідентифікації кластерів на регіональному рівні в контексті економікогеографічних підходів дозволить більш комплексно розглядати кластерний потенціал території, визначати довірчий інтервал і ідентифікувати кластерні структури на різних рівнях агрегації. Виклад основного матеріалу. У цій статті розглядаються економічні та економіко-географічні методичні підходи до ідентифікації регіональних кластерів (модель міжгалузевого балансу, мульти-секторний аналіз, коефіцієнти локалізації та спеціалізації, індекс Еллісона-Глейзера, метод найменших відстаней Дюрантон-Оверман, показники Пропульсивную і ін.); подано класифікацію методів ідентифікації регіональних кластерів, які враховують агрегацію територій; запропонована методика первинної оцінка кластерного потенціалу території та типологія галузей промисловості по співвідношенню регіональних і галузевих умов розвитку; аналізується індекс просторової кластеризації. Практична значимість даного дослідження обумовлена урахуванням геопросторових чинників кластеризації (MAUP) при проведенні ідентифікації регіональних кластерів, що дозволяє визначати географічні кордони і унікальний поріг кластеризації для кластерів на різних рівнях агрегації. Аналіз економікогеографічних підходів до ідентифікації регіональних кластерів з урахуванням геопросторових аспектів кластеризації дозволяє визначити ступінь концентрації / дисперсії на певних інтервалах відстаней з обгрунтуванням порогових значень кластеризації на разліних рівнях агрегації територій. $B u$ сновки та перспективи подальших досліджень. Економіко-географічний підхід до ідентифікації регіональних кластерів, на відміну від економічного, враховує фактор MAUP, що дозволяє використовувати іiі на різних рівнях агрегації і визначати географічні межі і унікальний поріг кластеризації. Однак, потребується подальше дослідження методик ідентифікації регіональних кластерів 3 метою розробки комплексного підхіду, який враховуватиме якомога більше факторів та дозволить максимально точно ідентифікувати потенційно можливі утворення кластерних формуваннь.

Ключові слова: регіональні кластери, економіко-географічний підхід, агрегація, просторові чинники, ідентифікація, кластерні структури.

\section{ANALYSIS OF ECONOMIC AND GEOGRAPHICAL APPROACHES TO IDENTIFICATION OF REGIONAL CLUSTERS}

Formulation of the problem. This article is devoted to the study of economic and geographical

${ }^{1}$ Васильченко Анастасія Олегівна, канд. екон. наук, доцент, доцент кафедри маркетингу та міжнародного менеджменту, Поліський державний університет, м. Пінськ, Республіка Білорусь.

Vasylchenko Anastasiia, Ph.D. of Economic, Associate Professor, Associate Professor of the Department of Marketing and International Management, Polessky State University, Pinsk, Republic of Belarus.

ORCID ID: 0000-0002-2765-9214

e-mail: vasilchenko.2012@inbox.ru

2 Дем'янов Сергій Олександрович, старший викладач кафедри маркетингу та міжнародного менеджменту, Поліський державний університет, м. Пінськ, Республіка Білорусь.

Demyanov Sergey, Senior Lecturer of the Department of Marketing and International Management, Polessky State University, Pinsk, Republic of Belarus.

ORCID ID: 0000-0002-3839-9622

e-mail: damienne@mail.ru 
approaches to cluster identification at the regional level. Most modern research on the identification of regional clusters is aimed at studying economic aspects, almost completely ignoring geospatial factors. The aim of the research is to analyze economic and geographical approaches to the identification of clusters at the regional level, taking into account the problem of variability of area units. The subject of the research is the study of approaches to the identification of clusters at the regional level. The study used such methods as: comparative, statistical, descriptive, systemic, analysis and synthesis. Research hypothesis. Identifying methodological limitations of cluster identification methods at the regional level in the context of economic and geographical approaches will allow a more comprehensive consideration of the cluster potential of the territory, determine the confidence interval and identify cluster structures at different levels of aggregation. The statement of basic materials. This article considers economic and economic-geographical methodological approaches to the identification of regional clusters (model of intersectoral balance, multisector analysis, localization and specialization coefficients, Ellison-Glaser index, Duranton-Overman method of the smallest distances, Propulsive indicators, etc.); the classification of methods of identification of regional clusters which take into account aggregation of territories is given; the technique of primary estimation of cluster potential of the territory and typology of industries on a parity of regional and branch conditions of development is offered; the index of spatial clustering is analyzed. The originality and practical significance of the research is due to the geospatial factors of clustering (MAUP) in the identification of regional clusters, which allows to determine the geographical boundaries and the unique clustering threshold for clusters at different levels of aggregation. Analysis of economic and geographical approaches to the identification of regional clusters taking into account the geospatial aspects of clustering allows to determine the degree of concentration / dispersion at certain intervals of distances with justification of clustering thresholds at different levels of aggregation. Conclusions and perspectives of further research. The economic-geographical approach to the identification of regional clusters, in contrast to the economic one, takes into account the MAUP factor, which allows to use it at different levels of aggregation and to determine geographical boundaries and a unique clustering threshold. However, further research is needed on methods for identifying regional clusters in order to develop an integrated approach that will take into account as many factors as possible and allow the most accurate identification of potential cluster formations.

Key words:

regional clusters, economic-geographical approach, aggregation, spatial factors, identification, cluster structures.

\section{АНАЛИЗ ЭКОНОМИКО-ГЕОГРАФИЧЕСКОЕ ПОДХОДЫ К ИДЕНТИФИКАЦИИ РЕГИОНАЛЬНЫХ КЛАСТЕРОВ}

Постановка проблемы. Эта статья посвящена исследованию проблематики экономикогеографических подходов к идентификации кластеров на региональном уровне. Большинство современных научных исследований идентификации региональных кластеров направлено на изучение экономических аспектов, практически полностью игнорируя картографии факторы. Целью данного исследования является анализ экономико-географических подходов к идентификации кластеров на региональном уровне с учетом проблемы сменности единиц площади. Предметом исследования выступает исследование подходов к идентификации кластеров на региональном уровне. В ходе исследования применены такие методы как: сравнительный, статистический, описательный, системный анализ и синтез. Гипотеза исследования. Выявление методических ограничений методов идентификации кластеров на региональном уровне в контексте экономикогеографических подходов позволит более комплексно рассматривать кластерный потенциал территории, определять доверительный интервал и идентифицировать кластерные структуры на различных уровнях агрегации. Изложение основного материала. В этой статье рассматриваются экономические и экономико-географические методические подходы к идентификации региональных кластеров (модель межотраслевого баланса, мульти-секторный анализ, коэффициенты локализации и специализации, индекс Эллисона-Глейзера, метод наименьших расстояний Дюрантон-Оверман, показатели Пропульсивную и др.) представлена классификация методов идентификации региональных кластеров, учитывающих агрегацию территорий; предложена методика первичной оценка кластерного потенциала территории и типология отраслей промышленности по соотношению региональных и отраслевых условий развития; анализируется индекс пространственной кластеризации. Практическая значимость данного исследования обусловлена учетом геопространственных факторов кластеризации (MAUP) при проведении идентификации региональных кластеров, позволяет определять географические границы и уникальный порог 
кластеризации для кластеров на разных уровнях агрегации. Анализ экономико-географических подходов к идентификации региональных кластеров с учетом геопространственных аспектов кластеризации позволяет определить степень концентрации / дисперсии на определенных интервалах расстояний с обоснованием пороговых значений кластеризации на разлиных уровнях агрегации территорий. Bblводы u перспективы дальнейших исследований. Экономикогеографический подход к идентификации региональных кластеров, в отличие от экономического, учитывает фактор MAUP, что позволяет использовать ее на различных уровнях агрегации и определять географические границы и уникальный порог кластеризации. Однако, требуется дальнейшее исследование методик идентификации региональных кластеров с целью разработки комплексный подход, учитывать как можно больше факторов и позволит максимально точно идентифицировать потенциально возможные образования кластерных формированиям.

\section{Ключевые слова:}

региональные кластеры, экономико-географический подход, агрегация, пространственные факторы, идентификация, кластерные структуры.

Постановка проблеми. Територіальнопросторове розміщення продуктивних сил призвело до поступового економічного розвитку одних регіонів і відставання у відповідному розвитку інших, тобто до сформування своєрідної нерівномірності соціально-економічного розвитку регіонів. Це сталося внаслідок ряду причин, серед яких: наявність чи відсутність корисних копалин, можливість їх вилучення і доступності, сприятливий клімат, територіальна концентрація суб'єктів господарювання та інфраструктури, чисельність населення, рівень освіти, кваліфікаційний склад, матеріально-виробничий потенціал та ін. умови, що сприяють розвитку економіки регіону. Рівень соціально-економічного потенціалу країни визначається розвитком їі територіальних утворень (регіонів), а ключовими параметрами регіонального розвитку виступають інноваційність і конкурентоспроможність, які забезпечують сталий розвиток регіону.

Для забезпечення стабільно високих темпів сталого розвитку регіону та підвищення його конкурентоспроможності доцільне застосування кластерного розвитку економіки. При ефективному формуванні внутрішньокластерних коопераційних зв'язків він принесе синергетичний ефект від діяльності суб'єктів господарювання та сприятиме розвитку профільних галузей економіки та формуванню багатогалузевої структури виробництва. Кластер стає ефективним засобом для подолання зацикленості на внутрішньофірмових проблемах, інертності, негнучкості та змов між конкуруючими структурами, які знижують або повністю блокують позитивний вплив конкуренції та появу нових суб'єктів підприємницької діяльності [1, с.43]. Відповідно, необхідна розробка державних програм регіонального кластерного розвитку, підтримки малого та середнього бізнесу, від ефективності реалізації яких залежить розвиток економіки країни.
Для застосування кластерного підходу необхідна оцінка потенціалу кластерного розвитку регіону, заснована на методиках ідентифікації регіональних кластерів. Відсутність логікоструктурної основи опису чітких меж кластерних структур породжує одночасно універсальність і розмитість застосування даної категорії. Впровадження механізмів системи державноприватного партнерства реалізує два способи формування регіональних кластерів «зверхувниз», так звана диригентська модель кластерної політики - при безпосередній участі держави i здійсненні формування кластерних утворень на підставі директивної політики держави і «знизувгору» або ліберальна модель кластерної політики - заснована на створенні сприятливих умови для об'єднання організацій схожих галузей господарювання, формування між ними ефективних коопераційних і колабораційних зв'язків.

Ліберальна модель характерна для країн 3 ліберальною економічною системою, яка близька до чистого капіталізму втілена в США, Австралії, Великобританії, Канади. Диригентська модель організації кластерної політики характерна для Японії, Південної Кореї, Франції, Сінгапуру. Основна відмінність між даними моделями полягає в посиленні (диригентська) і ослабленні (ліберальна) ролі держави в процесах утворення регіональних кластерів. Однак, важливо розуміти, що в різних країнах історично склалися різні умови для застосування тієї чи іншої моделі через відмінності в економіці, законодавстві та ін. факторах формування державності, тому те, що підходить одній державі абсолютно не підходить іншій. Крім того, кластерні формування всередині однієї держави також не $\epsilon$ ідентичними, тому, необхідний детальний аналіз підходів до вивчення кластерного потенціалу регіону. 
Аналіз останніх досліджень та публікацій. Актуальними дослідницькими напрямками ідентифікації регіональних кластерів $є$ методичні підходи, засновані на системному аналізі теоретичних і методичних аспектів ідентифікації кластерів, розробка комплексної моделі кластерної ідентифікації, а також оцінка рівня розвитку кластерів в Республіці Білорусь.

Е. Віітамо говорить про існування так званих жорстких (hard), м'яких (soft) методів, а також інструментарію М. Портера [2].

Підходи до ідентифікації кластерів, засновані на кількісних методиках, що спираються на економічне моделювання відносяться до числа жорстких методів і представлені в роботах Е. Бергмана, А. Джейфа, М. Ландмарка, Й. Лінквіста, Т. Маззарола, Е. Маркона, Д. Поуера, Е. Фезера. Ключовою особливістю підходів даних вчених $є$ генералізуючий спосіб ідентифікації регіонального кластера, заснований на індустріалізації, регіоналізації та інноватиці.

Принципово відмінна точка зору (м'який метод) представлена в роботах Р. Інь, Н. Літзель, А. Маркусена, Б. Робертса, П. Скрантона, О. Солвела, Р. Стімсона, Ю. Тераса, також в проектах, ініційованих Кластерною обсерваторією і Гарвардською школою бізнесу, які фокусували свою увагу на вивченні конкретного кластера 3 метою отримання якісної інформації про особливості його розвитку за допомогою експертів, побудові генеалогічного древа кластера.

До жорстких методів ідентифікації регіональних кластерів відносять:

1) ідентифікацію регіональних кластерів, засновану на теоретичних принципах економіки локалізації Маршалла, яка пізніше заново знайшла своє відображення в працях М. Портера, який розглядав іiі як фактор міжнародної конкурентоспроможності;

2) ідентифікацію регіональних кластерів, засновану на розрахунках різних спеціалізованих індикаторів (спеціалізації регіону, розроблена Європейською обсерваторією кластерів, локалізаційні коефіцієнти, коефіцієнти для географічної концентрації та ін.);

3) ідентифікацію регіональних кластерів, засновану на визначенні міжгалузевих відносин за допомогою таблиць «витрати-випуск»;

4) ідентифікацію регіональних кластерів, засновану на комплексному просторовому економетричному аналізі.

До м'яких методів відносять:

1) кейси;

2) опитування експертів та учасників кластеру;
3) Метод Дельфі, проведення фокусгрупового дослідження;

4) анкетування.

Однак, необхідно зауважити, що кількісні методи орієнтовані на ідентифікацію існуючих кластерів, в той час, як якісні - на опис існуючих зв'язків і структур всередині кластера. Відповідно, дві групи жорстких і м'яких методів необхідно розглядати як єдине ціле так як вони описують процес ідентифікації регіонального кластера з різних сторін.

Виклад основного матеріалу дослідження. Модель «витрати-випуск» являє собою матрицю, елементами якої є величини взаємного обміну продукцією або послугами між галузями або окремими територіями. Вона дозволяє виявити залежність між внутрішньою системою виробництва і споживання від зовнішнього ринку. Аналіз проводиться у вигляді таблиці, яка розбивається на 4 квадранта:

- перший відображає споживання кожної задіяної в економіці галуззю всіх видів вироблених продуктів (проміжне споживання);

- другий-кінцевий попит у різних його елементах (споживання домашніх господарств, споживання держави і некомерційних організацій, які обслуговують домашні господарства, валове накопичення основного капіталу, зміна запасів, чистий експорт (експорт мінус імпорт));

- у третьому представлена додана вартість кожної галузі (оплата праці, податки на виробництво за вирахуванням субсидій, підприємницький дохід, валовий прибуток);

- у четвертому часто відображається перерозподіл національного доходу.

Математично це виражається за допомогою моделі міжгалузевого балансу (модель Леонтьєва) і виглядає наступним чином (формула 1);

$$
\mathrm{X}=\mathrm{AX}+\mathrm{Y}
$$

$$
\begin{aligned}
& \text { де } \\
& X=\left(\begin{array}{c}
X_{1} \\
\vdots \\
X_{2}
\end{array}\right) \text { - вектор валового випуску; } \\
& A=\left(\begin{array}{ccc}
a_{11} & \cdots & a_{1 j} \\
\vdots & \ddots & \vdots \\
a_{i 1} & \cdots & a_{i j}
\end{array}\right)-\text { матриця прямих }
\end{aligned}
$$

витрат;

$$
Y=\left(\begin{array}{c}
Y_{1} \\
\vdots \\
Y_{i}
\end{array}\right) \text { - вектор кінцевого споживання. }
$$

Коефіцієнти прямих витрат $a_{i j}$ показують, скільки одиниць продукції і-ої галузі витрачається на виробництво однієї одиниці продукції в 
галузі ј. Вважається, що технології виробництва у всіх галузях залишаються незмінними (в розглянутий період часу), відповідно коефіцієнти прямих витрат також постійні. Стійкість галузевих технологій в моделі Леонтьєва дозволяє використовувати таблиці «витрати-випуск» не тільки на галузевому, а й на регіональному рівнях.

Для аналізу динаміки та структури показників зв'язку між учасниками регіонального кластера використовуються графічні методи, однак, вони можуть бути побудовані не тільки використовуючи інструменти теорії графів, а й застосовуючи звичайні мережеві графіки та діаграми.

Для ідентифікації регіональних кластерів використовують також спеціальні показники пропульсивності. Одним 3 таких показників $\epsilon$ коефіцієнт еластичності, який розраховується на основі кореляційно-регресійного моделювання, тобто відбувається оцінка зміни результату на основі факторної ознаки (формула 2):

$$
\ni_{x i}=a_{i} \times \frac{\bar{X}_{i}}{\bar{Y}}
$$

де $\bar{X}_{i}-$ середнє значення відповідної факторної ознаки; $\bar{Y}$ - середнє значення результативного ознаки; $a_{i}-$ коефіцієнт регресії при відповідній факторній ознаці.

Застосовуючи теорію порівняльних переваг розрахуємо коефіцієнт спеціалізації, який показує можливість «точок зростання» за рахунок орієнтації регіону на певний вид діяльності (формула 3):

$$
\mathrm{C}_{i r}=\frac{\alpha_{i r}}{\alpha_{r}}
$$

де $C_{i r}$ - коефіцієнт спеціалізації і-ї галузі в регіоні $\mathrm{r} ; \alpha_{i r}-$ частка регіону r в обсязі випуску і-ї галузі (виду економічної діяльності); $\alpha_{r}$ - частка регіону г в обсязі валового випуску в країні.

Формула Л. А. Стрижкової дозволяє визначити кількісне значення показника норми заміни трудових ресурсів основними виробничими фондами як один з показників пропульсивності (формула 4):

$$
\mathrm{N}(\mathrm{t}, \mathrm{t}-1)=\frac{\left(\Phi_{\mathrm{B}}(t)-\Phi_{\mathrm{B}}(t-1)\right)}{\frac{P_{\mathrm{T}}(t)}{P_{\mathrm{T}}(t-1)}-1}
$$

де $\mathrm{N}(\mathrm{t}, \mathrm{t}-1)$ - норма заміни за період; Фв (t), Фв (t-1), $P_{\mathrm{T}}(\mathrm{t}), \mathrm{P}_{\mathrm{T}}(\mathrm{t}-1)$ - фондоозброєність і продуктивність праці в кінці і на початку періоду, відповідно.

Один з методів просторової описової статистики використовується з метою інтерпретації кількісного аналізу даних з використанням географічних інформаційних систем. Мірою прос- торової однорідності є проста імовірнісна модель (процес Пуассона) на площі з постійною функцією інтенсивності. Для виявлення відхилень від просторової однорідності використовується K- i L- функції Ріплі, де функція К - оцінка просторової однорідності на підставі вибірки визначається наступним чином (формула 5):

$$
\widehat{K}(t)=\lambda^{-1} \sum_{i \neq j} \frac{I\left(d_{i j}<t\right)}{n}
$$

де $d_{i j}$ - евклідова відстань між і- й и ј- й точками в наборі даних з $\mathrm{n}$ точок, $\mathrm{t}$ - радіус пошуку, $\lambda$ - середня щільність точок (зазвичай оцінюється як $\mathrm{n} / \mathrm{A}$, де $\mathrm{A}$ - площа, що містить всі точки), а I - індикаторна функція (1 - якщо ії операнд істинний, 0 в іншому випадку). У двох вимірах, якщо точки приблизно однорідні, вони повинні бути приблизно рівні $\pi t^{2}$.

Модифікацією К-функції є L-функції (формула 6).

$$
\widehat{L}(t)=\left(\frac{\widehat{K}(t)}{\pi}\right)^{\frac{1}{2}}
$$

K-функція Ріплі допомагає визначити, чи мають точки випадковий, розосереджений або кластерний зразок розподілу в певному масштабi.

Підхід, заснований на принципах економіки локалізації Маршалла, дозволяє ідентифікувати кластери за допомогою визначення регіональної локалізації. Визначальним методом в даному підході $є$ метод фактору розташування.

Методично даний підхід має ряд переваг i обмежень: до переваг слід віднести доступність статистичних даних, простоту розрахунку та інтерпретації показників; до недоліків - відсутність уявлень про самодостатність еталонного регіону, складність обліку транспортних витрат всередині регіону, неможливість визначення вкладу підприємств в галузевий обсяг виробництва.

У сучасних економічних i економікогеографічних дослідженнях просторовий економетричний аналіз даних здійснюється досить рідко. Більшість досліджень проблематики ідентифікації регіональних кластерів обмежується порівняльним аналізом різних макроекономічних показників, не зачіпаючи просторові аспекти.

Методичний інструментарій оцінки географічної концентрації та регіональної спеціалізації включає кілька десятків методів. Однак питання агрегування досліджуваних територій i зміни даних в різних географічних масштабах ігноруються в більшості економікогеографічних і економічних досліджень. 
Проблема змінності одиниць площі (MAUP) є однією з слабовивчених проблем сучасної економіко-географічної методології ідентифікації регіональних кластерів. Дана методична проблема була піднята ще в 1934 р. [3], і детально вивчена С. Оупеншоу, який позначив основні методичні обмеження методів ідентифікації промислової концентрації і процесів агломерування промисловості [4].

Ще однією проблемою, яка істотно знижує цінність результатів, $є$ переривчастість простору. Економіко-географічні дослідження вра- ховують неоднорідність і переривчастість географічного простору. Внаслідок цього, отримані дані залежать від вибору меж досліджуваного району і цілей дослідження.

MAUP ілюструє необхідність обліку безперервності географічного простору і відходу від штучних одиниць просторової звітності. Аналіз, представлений в таблиці 1, відображає можливості та обмеження використання кожного 3 методів ідентифікації кластерів, в різному ступені враховують проблему змінності одиниць площі.

Таблиця 1 - Методичні обмеження методів ідентифікації кластерів

\begin{tabular}{|c|c|}
\hline Метод ідентифікації & Методичні обмеження і можливості застосування \\
\hline 1 & 2 \\
\hline $\begin{array}{l}\text { MAUP (проблеми змін- } \\
\text { ності одиниць площі) } \\
(1934,1981)\end{array}$ & $\begin{array}{l}\text { 1) Проблема змінюваних одиниць площі (MAUP) є джерелом статистичної } \\
\text { похибки, яка може вплинути на результати статистичних гіпотез; } \\
\text { 2) MAUP впливає на результати досліджень, коли точкові дані, засновані на } \\
\text { вивченні просторових явищ, об'єднуються в райони. Отримані підсумкові } \\
\text { значення MAUP впливають на визначення меж району; } \\
\text { 3) Проблема зміни результатів досліджень залежно від масштабів території. }\end{array}$ \\
\hline $\begin{array}{l}\text { Модель «витрати- } \\
\text { випуск» за матеріальни- } \\
\text { ми і нематеріальними } \\
\text { витратами }\end{array}$ & $\begin{array}{l}\text { 1) Дозволяє формально виміряти взаємозв'язки між галузями і виявити перед- } \\
\text { умови створення кластера; } \\
\text { 2) Не враховує потоки інформаційного обміну, обміну знаннями та людськи- } \\
\text { ми ресурсами. }\end{array}$ \\
\hline $\begin{array}{l}\text { Мульти-секторний якіс- } \\
\text { ний аналіз MSQA }\end{array}$ & $\begin{array}{l}\text { 1) Використовується для обгрунтування в основному політичних рішень регі- } \\
\text { онального управління з підтримки та розвитку ключових галузей і кластерів, } \\
\text { які можуть посилити конкурентоспроможність регіону в силу економічного } \\
\text { ефекту виробничих зв'язків між підприємствами кластера і синергетичного } \\
\text { ефекту }\end{array}$ \\
\hline $\begin{array}{l}\text { Коефіцієнти локалізації } \\
\text { та спеціалізації }\end{array}$ & $\begin{array}{l}\text { 1) Свідчать про концентрацію / спеціалізацію галузі в регіоні, а не про наяв- } \\
\text { ність кластерів; } \\
\text { 2) Необхідно доповнювати іншими методами; } \\
\text { 3) Немає чіткого порогового значення }\end{array}$ \\
\hline Коефіцієнт Джині & $\begin{array}{l}\text { 1) Індекс дозволяє виміряти нерівномірність розподілу доходів і кількісно ви- } \\
\text { міряти рівень концентрації доходів у найбільш високому квінтилі порівняно із } \\
\text { середнім доходом; } \\
\text { 2) Індекс з побудовою кривої Лоренца відображає ступінь концентрації еко- } \\
\text { номічної активності в регіоні; } \\
\text { 3) Математична складність розрахунків і чутливість результатів до агрегації } \\
\text { території. }\end{array}$ \\
\hline $\begin{array}{l}\text { Індекс концентрації } \\
\text { Кругмана }\end{array}$ & $\begin{array}{l}\text { 1) Свідчить про концентрацію / спеціалізацію галузі в регіоні, а не про наяв- } \\
\text { ність кластерів; } \\
\text { 2) Необхідно доповнювати іншими методами; } \\
\text { 3) Немає чіткого порогового значення. }\end{array}$ \\
\hline Індекс Еллісона-Глейзера & $\begin{array}{l}\text { 1) Індекс дозволяє виміряти надлишкову географічну концентрацію по відно- } \\
\text { шенню до промислової концентрації і відобразити ефект регіонального роз- } \\
\text { ташування; } \\
\text { 2) Індекс порівняємо між галузями та інваріантний до змін просторової кла- } \\
\text { сифікації. }\end{array}$ \\
\hline
\end{tabular}


Продовження табл. 1

\begin{tabular}{|c|c|}
\hline 1 & 2 \\
\hline $\begin{array}{l}\text { Метод найменших відс- } \\
\text { таней Дюрантона- } \\
\text { Овермана }\end{array}$ & $\begin{array}{l}\text { 1) У порівнянні з просторово-агрегованими показниками, Індекс найменших } \\
\text { відстаней дозволяє визначити тільки просторові розміри кластера, тому що } \\
\text { відображає значення просторової концентрації / дисперсії для окремих інтер- } \\
\text { валів. }\end{array}$ \\
\hline Графічні методи & $\begin{array}{l}\text { 1) Відносна простота і наочність; } \\
\text { 2) Чіткі правила формування моделей; } \\
\text { 3) Гнучкість і універсальність; } \\
\text { 4) Не завжди дає детальну інформацію про об'єкт дослідження. }\end{array}$ \\
\hline $\begin{array}{l}\text { Показники пропульсив- } \\
\text { ності (коефіцієнт спеціа- } \\
\text { лізації, показник норми } \\
\text { заміни, коефіцієнт елас- } \\
\text { тичності та ін.) }\end{array}$ & $\begin{array}{l}\text { 1) Допомагають визначити спеціалізацію регіону; } \\
\text { 2) Визначають ступінь залежності і взаємозв'язку між різними показниками; } \\
\text { 3) Характеризують рівень технічної субституції або «запасу економічної міц- } \\
\text { ності» за напрямом економічної діяльності; } \\
\text { 4) Мають вузьку спеціалізацію, не дають повної картини аналізу ринку регіо- } \\
\text { ну. }\end{array}$ \\
\hline
\end{tabular}
Джерело: розроблено авторами на підставі [5-7]

При використанні методологічного інструментарію ідентифікації кластерів значний вплив на достовірність і об'єктивність отриманих результатів надають такі Обмежуючі фактори:

1. Результати ідентифікації кластерів залежать від обраного рівня агрегування. Отримані дані при переході з одного рівня агрегування на інший можуть значною мірою відрізнятися;
2. Індекси не забезпечують чітке формулювання порогу спеціалізації, що вказує на наявність кластерів;

3. Індекси не можуть виявити просторові розміри кластера, за винятком локальних територій з високим рівнем спеціалізації.

Порівняльний аналіз методів ідентифікації регіональних кластерів з урахуванням просторового фактора MAUP дозволяє виділити 3 категорії методів (рисунок 1).

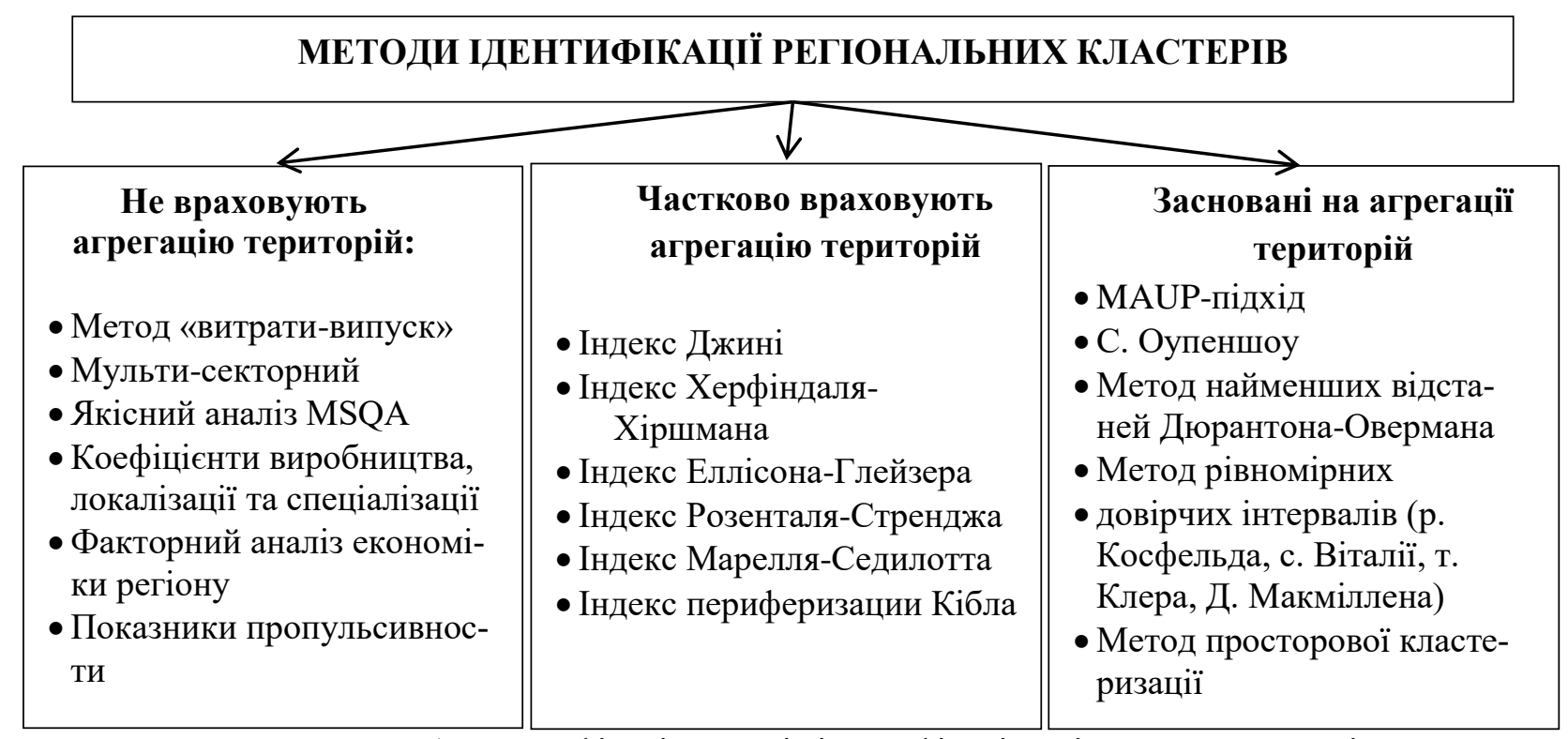

Рисунок 1 - Класифікація методів ідентифікації регіональних кластерів

Джерело: розроблено авторами

Геопросторовий аналіз на різних таксономічних рівнях дозволяе визначити географічні межі і структурні елементи кластера як системи 3 достатньою деталізацією ядра і стейкхолдерів.

Ідентифікація регіональних кластерів також передбачає факторний аналіз економіки регіону. Факторний аналіз дозволяе визначити внесок національного, регіонального та галузевого факторів у зміни значень змінної (таблиця 2). 
Таблиця 2 - Первинна оцінка кластерного потенціалу та факторний аналіз економіки

\begin{tabular}{|c|c|c|c|}
\hline Метод & Показник & Формула розрахунку показника & $\begin{array}{c}\text { Інтерпретація } \\
\text { результатів }\end{array}$ \\
\hline $\begin{array}{l}\text { Оцінка } \\
\text { ступінь } \\
\text { локалізація }\end{array}$ & $\begin{array}{l}\text { Індекс локаліза- } \\
\text { ціï } \\
\left(\mathrm{LQ}_{\text {index }}\right)\end{array}$ & $\begin{array}{l}\qquad L Q_{i}=\frac{l_{i} / l}{L_{i} / L} \\
\text { де } l_{i}-\text { зайнятість в } i \text { галузі в регіоні; } l \\
\text { - загальна кількість зайнятих в регі- } \\
\text { оні; } L_{i}-\text { зайнятість в } i \text { галузі в країні; } \\
L-\text { загальна кількість зайнятих в кра- } \\
\text { їні. }\end{array}$ & $\begin{array}{l}\text { Якщо величина } L Q \text { більше } \\
1 \text {, то галузь володіє класте- } \\
\text { рним первинним кластер- } \\
\text { ним потенціалом. }\end{array}$ \\
\hline \multirow{2}{*}{$\begin{array}{l}\text { Метод струк- } \\
\text { турних зру- } \\
\text { шень (Shift- } \\
\text { Share } \\
\text { аналіз) }\end{array}$} & $\begin{array}{l}\text { Національний } \\
\text { фактор (NS) }\end{array}$ & $\begin{array}{l}\quad \mathrm{NS}=\mathrm{l}_{\mathrm{t}-1}^{\mathrm{i}}\left(\frac{\mathrm{L}_{\mathrm{t}}}{\mathrm{L}_{\mathrm{t}-1}}-1\right) \\
L_{t} \text { і } L_{t-1} \text { - загальна кількість зайнятих } \\
\text { в країні в періоди } t \mathrm{i}(t-1) \text { відповід- } \\
\text { но } l_{t-1}^{i}-\text { зайнятість в } i \text { галузі в регіо- } \\
\text { ні в період }(t-1) \\
L_{t}^{i} \text { і } L_{t-1}^{i}-\text { кількість зайнятих в } i \text { га- } \\
\text { лузі в країні в період } t \mathrm{i}(t-1) \text { відпо- } \\
\text { відно }\end{array}$ & $\begin{array}{l}\text { Національний фактор відо- } \\
\text { бражає ступінь впливу на- } \\
\text { ціональних тенденцій зрос-- } \\
\text { тання змінної на регіональ- } \\
\text { ні тенденції зростання. }\end{array}$ \\
\hline & $\begin{array}{l}\text { Галузевий } \\
\text { фактор (IM) }\end{array}$ & $\begin{array}{l}I M=l_{i-1}^{i} \times\left(\frac{L_{t}^{i}}{L_{t-1}^{i}}-\frac{L_{t}}{L_{t-1}}\right) \\
L_{t} \text { і } L_{t-1}-\text { загальна кількість зайнятих } \\
\text { в країні в періоди } t \mathrm{i}(t-1) \text { відповідно } \\
l_{t-1}^{i}-\text { зайнятість в } i \text { галузі в регіоні в } \\
\text { період }(t-1) \\
L_{t}^{i} \text { i } L_{t-1}^{i}-\text { кількість зайнятих в } i \text { га- } \\
\text { лузі в країні в період } t \mathrm{i}(t-1)\end{array}$ & $\begin{array}{l}\text { Галузевий фактор показує } \\
\text { ступінь впливу національ- } \\
\text { них галузевих тенденцій } \\
\text { зростання на регіональні } \\
\text { галузеві тенденції. }\end{array}$ \\
\hline \multirow[t]{2}{*}{$\begin{array}{l}\text { Метод струк- } \\
\text { турних зру- } \\
\text { шень (Shift- } \\
\text { Share } \\
\text { аналіз) }\end{array}$} & $\begin{array}{l}\text { Регіональний } \\
\text { фактор (RS) }\end{array}$ & $\begin{array}{l}\quad R S=l_{t-1}^{i} \times\left(\frac{l_{t}^{i}}{l_{t-1}^{i}}-\frac{l_{t}^{i}}{L_{t-1}^{i}}\right) \\
L_{t} \text { і } L_{t-1} \text { - загальна кількість зайнятих } \\
\text { в країні в періоди } t \text { i }(t-1) \text { відповідно } \\
l_{t-1}^{i}-\text { зайнятість в } i \text { галузі в регіоні в } \\
\text { період }(t-1) \\
L_{t}^{i} \text { і } L_{t-1}^{i}-\text { кількість зайнятих в } i \text { га- } \\
\text { лузі в країні в період } t \text { i }(t-1) \text { відпо- } \\
\text { відно }\end{array}$ & $\begin{array}{l}\text { Галузі промисловості, що } \\
\text { характеризуються високи- } \\
\text { ми значеннями RS, мають } \\
\text { значний кластерний потен- } \\
\text { ціал і відносяться до про- } \\
\text { пульсивних; галузі з нега- } \\
\text { тивними значеннями регіо- } \\
\text { нального фактора } є \text { аутсай- } \\
\text { дерами }\end{array}$ \\
\hline & $\begin{array}{l}\text { Структурний } \\
\text { зсув (SS) }\end{array}$ & $S S=\mathrm{NS}+\mathrm{IM}+\mathrm{RS}$ & $\begin{array}{l}\text { SS дозволяє визначити за- } \\
\text { гальний приріст змінної з } \\
\text { урахуванням впливу Наці- } \\
\text { онального, галузевого та } \\
\text { регіонального факторів }\end{array}$ \\
\hline
\end{tabular}

Джерело: розроблено авторами на підставі [8]

Національний фактор відображає ступінь впливу національних тенденцій зростання змінної на регіональні. Галузевий фактор для ідентифікації галузевих кластерів є вкрай важливим і дає уявлення про вплив галузевих тенденцій національного рівня на тенденції на регіональному рівні. Регіональний фактор відіграє визначальну роль в ідентифікації регіональних кластерів, оскільки дозволяе визна- чити пропульсивні і депресивні галузі в регіоні на основі зіставлення показників темпу зростання змінної на національному та регіональному рівнях.

3 метою виділення лідируючих галузей, які здатні створити ядро кластера, доцільно використовувати типологію галузей промисловості по співвідношенню показників RS i $\mathrm{IM}$, представлену в таблиці 3 . 
Таблиця 3 - Типологія галузей по співвідношенню показників RS i IM

\begin{tabular}{|c|c|c|c|}
\hline $\begin{array}{c}\text { Тип } \\
\text { галузі }\end{array}$ & $\begin{array}{c}\text { Співвідношення } \\
\text { показників }\end{array}$ & \multicolumn{1}{|c|}{ Інтерпретація показників } \\
\hline 1 & $\mathrm{RS}>0, \mathrm{IM}>0$ & Сприятливі регіональні та галузеві умови розвитку \\
\hline 2 & $\begin{array}{c}\mathrm{RS}>0, \mathrm{IM}<0 \\
|\mathrm{RS}|>|\mathrm{IM}|\end{array}$ & $\begin{array}{l}\text { Сприятливі регіональні умови розвитку переважають над менш } \\
\text { сприятливими галузевими умовами зростання }\end{array}$ \\
\hline 3 & $\begin{array}{c}\mathrm{RS}<0, \mathrm{IM}>0 \\
|\mathrm{RS}|<\mid \mathrm{IM}\end{array}$ & $\begin{array}{l}\text { Сприятливі галузеві умови розвитку переважають над менш } \\
\text { сприятливими регіональними умовами зростання }\end{array}$ \\
\hline 4 & $\begin{array}{c}\mathrm{RS}>0, \mathrm{IM}<0 \\
|\mathrm{RS}|<|\mathrm{IM}|\end{array}$ & $\begin{array}{l}\text { Сприятливі регіональні умови розвитку не можуть перевищити } \\
\text { несприятливі галузеві умови зростання }\end{array}$ \\
\hline 5 & $\begin{array}{c}\mathrm{RS}<0, \mathrm{IM}>0 \\
|\mathrm{RS}|>|\mathrm{IM}|\end{array}$ & $\begin{array}{c}\text { Сприятливі галузеві умови розвитку не можуть перевищити } \\
\text { несприятливі регіональні умови зростання }\end{array}$ \\
\hline 6 & $\mathrm{RS}<0, \mathrm{IM}<0$ & Несприятливі регіональні та галузеві умови розвитку \\
\hline
\end{tabular}

Перший і другий типи галузей промисловості відносяться до числа регіональних лідерів. Галузі першого типу мають найбільший кластерний потенціал, галузі другого типу також здатні сформувати ядро кластера. Галузі третього типу в меншій мірі мають здатність утворити ядро кластера, оскільки регіональні умови зростання не стільки сприяють, скільки перешкоджають їх розвитку. Галузі четвертого і п'ятого типів не в змозі утворити ядро кластера.
Для візуалізації результатів проведеного факторного аналізу галузей промисловості будуються карти кластерних компонентів відповідно до значень регіонального та галузевого факторів і масштабуванням ключових компонентів кластера за індексом локалізації.

Побудова карт кластерних компонентів необхідна для коректного відбору лідируючих кластерних компонентів. Даний відбір здійснюється на основі трьох критеріїв, представлених в таблиці 4.

\section{Таблиця 4 - Критерії віднесення галузей промисловості до ключових компонентів}

\begin{tabular}{|l|l|}
\hline \multicolumn{1}{|c|}{ Показник } & \multicolumn{1}{|c|}{ Критерій } \\
\hline Індекс локалізації (LQ) & $\mathrm{LQ>0,8} \mathrm{не} \mathrm{менше} \mathrm{двох} \mathrm{разів} \mathrm{протягом} \mathrm{аналізованого} \mathrm{періоду}$ \\
\hline Регіональний компонент (RS) & $\mathrm{RS}>0$ не менше двох разів протягом аналізованого періоду \\
\hline $\begin{array}{l}\text { Співвідношення регіонального } \\
\text { та галузевого компонентів }(R S \text { и } \\
I M)\end{array}$ & $\begin{array}{l}\text { Співвідношення компонентів дозволяє зарахувати галузь до } \\
1,2 \text { або 3 типу }\end{array}$ \\
\hline
\end{tabular}

Джерело: розроблено авторами

Відсутність конкретного порогу значень агломераційних ефектів для ідентифікації кластерів і неможливість статистичного підтвердження реальної локалізації підприємств не дозволяють отримати достовірний результат. Як рішення зазначених недоліків вимірювань представляється необхідним використання методу найменших відстаней.

Метод дозволяє визначити географічні параметри регіонального кластера за допомогою аналізу даних концентрації і дисперсії конкретних об'єктів на окремих інтервалах відстаней. Обмеженням даного методу служить неможливість обліку просторового розміщення підприємств при визначенні ступеня дисперсії або концентрації на певній відстані. Однак просторові агреговані метрики дозволяють визначити вузькоспеціалізовані регіони, де рівень концентрації досить високий.

Індекс просторової кластеризації заснований на загальних принципах методу ортодромічних відстаней, однак відрізняється за методикою розрахунку та інтерпретації обчислюваних відстаней.

Слід визначити ключові властивості оцінки ступеня просторової кластеризації:

1) Індекс просторової кластеризації демонструє геолокацію підприємств 3 високим ступенем кластеризації, що дає уявлення про межі і просторовому вимірі кластера; 
2) Індекс просторової кластеризації відносно невисокі обчислювальні вимоги в порівнянні з іншими методами, і може бути використаний на різних рівнях агрегації;

3) методичний підхід до розрахунку індексу просторової кластеризації дозволяє визначити ступінь концентрації або дисперсії підприємств у географічному просторі;

4) інтерпретація розрахунків індексу просторової кластеризації дозволяють визначити ступінь концентрації / дисперсії промислових підприємств у просторі;

5) Методика розрахунку дозволяє визначити унікальний поріг кластеризації для кожного окремого підприємства як інтервал масштабованої змінної.

Методика розрахунку індексу просторової кластеризації передбачає визначення геопросторової локалізації суб'єктів кластера за допомогою обробки даних GPS і вимірювання ортодромічних відстаней між усіма можливими парами підприємств на заданому рівні агрегації. Відповідно до даної методики, розрахунок унікального порога концентрації / дисперсії проводиться для кожного потенційного суб'єкта кластера за такою формулою 7:

$$
\operatorname{ISC}_{\mathrm{i}}=\frac{1}{\mathrm{j}-1} \sum_{\mathrm{j}=1,}^{\mathrm{j}}\left(\mathrm{f}\left(\mathrm{d}_{\mathrm{i}, \mathrm{j}}\right)\right)^{-1}
$$

де $\mathrm{ISC}_{\mathrm{i}}$ - Індекс просторової кластеризації; $f\left(d_{i, j}\right)$ - означає всі можливі перевернуті функції, які обчислюють ортодромічну відстань між двома точками; $\mathrm{j}$ - число унікальних пар об'єктів.

Особливістю даного методу є розрахунок довірчого інтервалу для кожного 3 підприємств 3 метою визначення концентрації або дисперсії суб'єктів кластера на певній відстані. Розрахунок індексів повинен спиратися на знаходження середнього значення для кожного унікального суб'єкта, що дозволить визначити середній довірчий інтервал для регіону, який може бути витлумачений як поріг кластеризації. Ідентифікація регіональних кластерів за допомогою розрахунку індексу просторової кластеризації дозволяє найбільш повно розглянути економіко-географічні аспекти формування кластерів і максимізувати прив'язку розрахункових показників до конкретної території або регіону.

Висновки та перспективи подальших досліджень. В результаті проведених науко- вих досліджень слід зробити наступні висновки:

1. Неможливість математичного вираження певних процесів формування регіонального кластера і відсутність комплексних методик ідентифікації регіональних кластерів значно ускладнюють наукові дослідження даної проблематики. Більшість розроблених методик ідентифікації кластерних структур не враховує фактор MAUP, що $є$ методичним обмеженням для вивчення кластерів на різних рівнях агрегації.

2. Методика ідентифікації регіональних кластерів припускає використання як традиційних методів оцінки просторової концентрації (первинний аналіз кластерного потенціалу, факторний аналіз, побудова карт кластерних компонентів), так і оцінку просторової кластеризації, що дозволяє визначити географічні межі кластера за допомогою оцінки ступеня концентрації/дисперсії на певних інтервалах відстаней $з$ обгрунтуванням порогових значень кластеризації для різних рівнів агрегації території з урахуванням проблеми змінності одиниць площі.

3. Економіко-географічний підхід до ідентифікації регіональних кластерів, на відміну від економічного, враховує фактор MAUP, що дозволяє використовувати iii на різних рівнях агрегації і визначати географічні межі і унікальний поріг кластеризації.

\section{Література}

1. Соколова И. С. Кластерный подход в формировании конкурентных преимуществ субъектов малого предпринимательства. Российское предпринимательство. 2010. - № 5. - C. 40-44.

2. The International Institute for Applied Systems Analysis. [Електроний ресурс]. Peжим доступа: http://www.iiasa.ac.at/Publications/Documents /IR-01-016.pdf

3. Gehlke C. E., Biehl K. Certain effects of grouping upon the size of the correlation coefficient in census tract material. Journal of the American Statistical Association. 1934. № 29 (185A). P. 169-170.

4. Openshaw S. The modifiable areal unit problem. Concepts and Techniques in Modern Geography. 1984. Vol. 38. 
5. Duranton Gilles, Overman Henry G. Testing for Localization Using Micro-Geographic Data. Review of Economic Studies. 2005. № 72. P. 1077-1106.

6. Krugman P. Development, geography and economic theory. Cambridge: MIT Press, 1995. $127 \mathrm{p}$.

7. Porter M. E. Clusters and the New Economics of Competition. Harvard Business Review. 1998. November-December. P. 77-90.

8. Ковалева Т. Ю. Алгоритм идентификации и оценки кластеров в экономике региона. Вестник Пермского университета, 2011. Вып. 4. С. 30-39.

\section{References}

1. Sokolova, I. S. (2010). Cluster approach in the formation of competitive advantages of small business entities. Moscow: Russian entrepreneurship, 5, 40-44.

2. The International Institute for Applied Systems Analysis (2021). Retrived from:

Стаття надійшла

до редакції : 15.06.2021 p.
http://www.iiasa.ac.at/Publications/Documents /IR-01-016.pdf

3. Gehlke, C. E., Biehl, Katherine (1934). Certain effects of grouping upon the size of the correlation coefficient in census tract material. Journal of the American Statistical Association, 29 (185A), 169-170.

4. Openshaw S. (1984). The modifiable areal unit problem. Concepts and Techniques in Modern Geography, 38.

5. Duranton, Gilles, Overman, Henry G. (2005). Testing for Localization Using MicroGeographic Data. Review of Economic, 72, 10771106.

6. Krugman, P. (1995). Development, geography and economic theory. Cambridge: MIT Press, 127.

7. Porter, M. E. (1998). Clusters and the New Economics of Competition. Harvard Business Review, November-December, 77-90.

8. Kovaleva, T. Yu. (2011). Algorithm of identification and evaluation of clusters in the economy of the region. Bulletin of the Perm University, 4, 30-39.

Стаття прийнята

до друку: 30.09.2021 p.

Бібліографічний опис для цитування :

Васильченко А. Аналіз економіко-географічних підходів до ідентифікації регіональних кластерів / А. О. Васильченко, С. О. Дем'янов // Часопис економічних реформ. - 2021. № 3 (43). - C. 11-21. 